\title{
A Macroeconometric Model for the Sudan Economy: Empirical Evidence from Error Correction Framework 1956-2010
}

\author{
Khalafalla Ahmed Mohamed Arabi \\ Professor of Econometrics, Department of Econometrics \& Social Statistics \\ Faculty of Economics and Administrative Sciences, University of Bakht Al -Ruda, Sudan \\ Tel: 249-911-811-733_E-mail: khalaf_arabi@yahoo.com \\ Suliman Zakaria Suliman Abdalla \\ Assistant Professor, Department of Quantitative Analysis \\ College of Business Administration, King Saud University, Saudi Arabia \\ Tel: 966-56-084-7037 E-mail: sulimanzakaria9@yahoo.com
}

$\begin{array}{lcc}\text { Received: December 12, } 2012 & \text { Accepted: January 18, } 2013 & \text { Online Published: March 7, } 2013 \\ \text { doi:10.5430/rwe.v4n1p95 } & \text { URL: http://dx.doi.org/10.5430/rwe.v4n1p95 }\end{array}$

\begin{abstract}
This paper aims to build a macroeconometric model for the Sudan economy to be used as an analytical tool to describe the operation of the economy. The model comprises six equations built around the Keynesian identity with 12 macroeconomic variables. Based on error correction model framework, Engle-Granger two steps method was followed and a system of simultaneous equations was estimated by Three Stages Least Squares. The empirical results show that the error correction terms which exemplify the disequilibrium state and the short-run and long-run effects got the right sign and magnitude.
\end{abstract}

Keywords: Macroeconometric model, Error correction, Three-stage least squares, Sudan economy

\section{Introduction}

Over the past several decades, macroeconomic models building has been one of the most important activities used for explaining the empirical behavior of an actual economic system and for formulating economic policies almost in every country in the world. It is widely accepted that macroeconometric models serve the purposes of testing macroeconomic hypotheses, simulating the effects of alternative policies, and forecasting changes in the economy.

The pioneering work on the construction of macroeconometric models can be traced back to the work of Jan Tinbergen (1939). Since that time, a number of policymaking institutions and academic researchers have developed macroeconometric models to shed light on the domestic output growth and inflation trends, reaction of monetary and fiscal policies in the face of unexpected shocks and the prospects of macroeconomic stability. For example some researchers have developed macroeconometric models focusing on single country, [see for example, Klein and Goldberger (1955); Klein, et al. (1961); and Duesenberry, et al. (1965)]. Some researchers focus on multi-country macroeconometric models that are currently in use [see for example, Edison, Marquez, and Tryon (1987); Gagnon (1991); Helliwell, et al. (1990); McKibbin and Sachs (1991) and Meredith (1989)].

Macroeconomic modeling is generally motivated by two objectives: forecasting and more significantly, policy analysis. In pursuit of both these objectives, every model must ideally satisfy four criteria. First and foremost, it must fit into a theoretical framework. Second, the actual specification of the model must reflect a clear understanding of the contextual framework within which policies are formulated and executed along with an envisaged process of adjustment. Third, it is essential that the model is built on a firm and rich data base and, finally, the estimated structural model must adequately utilize the rigors and sophistications of econometric methodology (Pandit, 1999).

Macroeconometric models are systems of equations designed to represent the basic quantitative interrelationships among, and the behavior over time of, such major macroeconomic variables as national income, consumption, investment, employment, the price level, etc. The equations in macroeconometric models describe the behavior of 
consumers, producers, investors, and other groups of economic agents; they also summarize the market characteristics, institutional conditions, and technological requirements that guide and constrain economic action. They include variables selected to represent the major systematic factors entering each of these functions and relate these variables by means of statistical estimates of their net marginal effects. The estimation of these unknown parameters is based on the assumption that all the principal factors affecting the relationship have been properly identified, leaving only random disturbances with expected values of zero. Ideally, these residual disturbance terms should be small, not serially correlated, and not associated with the systematic factors (Zarnowitz, 1973).

Evaluation of the impacts of macroeconomic policies through developing a macroeconometric model is of crucial importance for economists and policy makers in Sudan, especially after the separation of the southern Sudan in July 2011. Such model can providing an empirical framework for addressing important issues such as the implications of the alternative monetary, fiscal and trade policy measures.

The main purpose of this paper is to build a macroeconometric model for the Sudan to be used as an analytical tool to describe the operation of the economy. The rest of this paper is proceeds as follows. Section 2 provides literature review of macroeconometric modeling. Section 3 presents the methodology and describes the data used in estimation. Section 4 illustrates the structure of the model. The empirical econometric results for the model are presented in Section 5 and finally, section 6 concludes the paper.

\section{Literature Review}

Over the years, the state of macroeconomic modeling and the use of macroeconomic models in policy analysis have been well researched by academics around the world and have come under heavy criticism. Different methods of analysis have yielded different results, sometimes sharply different, sometimes modestly.

Bhanumurthy etal (2012) analyzed the impact of transmission of international oil prices and domestic oil price pass-through policy on major macroeconomic variables in India with the help of a macroeconomic policy simulation model. Three major channels of transmission viz. import channel, price channel, and fiscal channel are explored with the help of a structural macroeconomic framework. Overall, they argue that the pass-through has differential impact on growth and inflation over the 12th Plan period. Hence, the policy of oil price deregulation must be carefully weighed and prioritized.

Janeš (2012) developed a single equation microeconomic Error Correction Model (ECM) with the Engle-Granger (1987) two step method. With the ECM approach he performed application on the key performance indicator (KPIs) and estimated short and long term effects between them. Final ECM indicates that that there is a lot of nonlinearity at the microeconomic level between KPIs and that a two step method should be used for the time series (KPIs) analyses at the microeconomic level and for forecasting.

Arabi (2012) analyzed the Sudanese economy via Investment - Saving gap, and Import - Export gap, identified the essential factors that affect economic growth. The most important results are the dominance of Investment - Saving gap over Import - Export gap, low level of labor productivity, low level of total factor productivity which reflects the decrease in technological level of the Sudanese economy, the growth rate of capital productivity is three time the growth of labor productivity. Factors that cause Investment - Saving gap are excess capacity, capital productivity, reliance on primary production as a main source of economic activity, while those which cause Import - Export gap are real exchange rate, terms of trade, and investment. The influence of Investment - Saving gap on growth is obvious compared to the other gap.

Asari etal (2011) used time-series Vector Error Correction Model (VECM) approach of stationarity test, cointegration test, stability test and Granger causality test. Impulse Response Function (IRF) has also been generated to explain the response to shock amongst the variables. The results show that the inflation rate impacts the interest rate as indicated by Granger-cause. Subsequently the interest rate influences the exchange rate as shown by the Granger cause test. Taking into account a long term relationship, interest rate moves positively while inflation rate goes negatively towards exchange rate volatility in Malaysia. The implication of this study is that increasing the interest rate can be efficient in restraining exchange rate volatility. Future researchers should attempt to use panel data and cover longer study duration of above10 years by using other variables.

Keele and De Boef (2004) used simulated data to demonstrate the equivalency between auto-distributed lag models and error correction models. They re-estimate a model of Supreme Court approval from the literature to demonstrate how the use of an error correction model enhances our understanding of political dynamics.

Lau Sau-Him Paul (2004) explained why examining the long-run effects of temporary changes in investment share on per capita output provides indirectly the answer regarding the effects of (possibly hypothetical) permanent changes in 
investment share, when per capita output and per capita investment are cointegrated. Applying the proposed method to the post-war data of major industrial countries, it is found that a disturbance to investment share does not produce a positive long-run effect in each of the four countries - France, Italy, Japan and the UK - in which per capita output and per capita investment are cointegrated. The evidence is unfavourable to the class of endogenous growth models.

Arabi (2002) built macroeconometric for the Sudan economy containing 27 equations. The model covered the real sector, monetary sector, prices, labor, fiscal sector, and the external sector. He estimated the model by 3SLS.

De Boef (2000) focused on two commonly used estimators: the Engle-Granger two-step estimator and generalized error correction. She considered the important role of simultaneity and discussed implications for the conclusions political scientists have drawn about the nature, even the existence, of equilibrium relationships between political processes. She found that even small violations of the permanent memory assumption can present substantial problems for inference on long-run relationships in situations that are likely to be common in applied work in all fields and suggest ways that analysts should

Alogoskoufis (1991) described the historical evolution of ECMs. He demonstrated that error correction models impose strong and testable non-linear restrictions on dynamic econometric equations, and that they do not obviate the need for modeling the process of expectations formation. With the exception of a few special cases, both the nonlinear restrictions and the modeling of expectations have been ignored by those who have treated ECMs as merely reparameterisations of dynamic linear regression models or vector autoregressions.

A.Al-Muatwaa (1991) built macroeconometric model of United Arab Emirate comprising four main blocks i.e. Production, Expenditure, Labor, Prices and Wages. Oil production is explained by oil exports. Non-tradable goods depend on number of workers, and net gross fixed capital formation as a proxy to capital stock.

Al-Hajji (1987) used monetary approach to built macroeconometric model for Saudi Arabia. The model comprises Aggregate demand equations, government sector, production and expenditure, money market and prices, labor, and foreign trade. Real imports depend on money supply, real income, relative imports price, and net foreign assets.

Mohamed Ahmed (1980) built macroeconometric model containing 18 equations, 10 are behavioral and 8 are identities. He divided the Sudan economy into two sectors i.e. the modern sector and the traditional sector.

Marzouk (1973) built the first macroeconometric model for the Sudan economy, aiming at predicating the future path of the Sudanese economy. He divided the economy into main blocks representing the productive sector, income and expenditure, income and expenditure, labor market, and foreign trade. Furthermore he desegregated production into value added by sector including agriculture, industry, transport, commerce, and services, and income and expenditure into private and government expenditure. The model was estimated by OLS using single equation.

\section{Methodology and Data}

\subsection{Equilibrium}

An equilibrium is defined as one in which there is no inherent tendency to change. The statistical concept of equilibrium centres on that of a stationary process. The short-run error or discrepancy between outcome and postulated equilibrium has a fixed distribution centered on zero that is there no tendency to grow over time. However since error represents shocks that are constantly occurring and affecting economic variables. In real economic system there is no systematic tendency for this error to diminish over time either. A sustainable long-run equilibrium relationship is something from which variables involved can deviate but not by any ever-growing amount. That is the error in the relationship cannot be integrated of any order greater than zero Banerjee etal (1993).

\subsection{Integration}

A series $X_{t}$ is said to be "integrated of order d" if one can obtain a stationary series by "differencing" the series d times $X_{t} \sim I(d)$ (Charemza 1992). To test the order of integration Augmented Dickey-Fuller (ADF) is the most commonly used to test the significance of the coefficient $\delta$ in the equation $\Delta Y_{t}=\delta Y_{t-1}+\sum_{i=1}^{n} \theta_{i} \Delta Y_{t-1}+\varepsilon_{t}$ under the null hypothesis $\delta=1$.

\subsection{Cointegration}

If there exists a vector $\beta$ such that the disturbance term from the regression $\left(\hat{\mu}=y_{t}-\hat{\beta} x_{t}\right)$ is of lower order of integration $I(d-b) ; b>0$ the Engle -Granger defined $y_{t}$ and $x_{t}$ as cointegrated of order $(d, b)$.

\subsection{Error Correction}

The major reason why relationships are not always in equilibrium centres on the inability of economic agents to adjust to new information instantaneously. The cost of adjustment results in the current value of the dependent variable being 
determined by the current and past values of some explanatory variable. The dynamic model suffers from many problems that is: the likely high level of correlation between current and lagged values of a variable; misspecification; spurious regression. A more suitable approach is to adopt the error correction formulation (ECM) of the dynamic model which has several distinct advantages and with the cointegration of model variables it incorporates both the short-run and the long-run effects Harris (1995)

3.4.1 Engle-Granger Error Correction method is composed of two steps: at first a static (long-run) model is estimated and its lagged residuals $\left(Y_{t-1}-\alpha_{0}-\hat{\beta} X_{t-1}\right)$ enter the first difference equation with minus sign $\Delta Y_{t}=\alpha_{0}+$ $\sum_{t=0}^{n} \alpha_{2 t} \Delta X_{t-1}-\gamma\left(Y_{t-1}-\alpha_{0}-\hat{\beta} X_{t}\right)+v_{t}$ in the second step. The estimated coefficient $\gamma$ measures the speed of adjustment. It is worthy to mention that the error correction term means that if the lagged dependent variable greater than the disequilibrium the current one will be decreased in the subsequent period.

3.4.2 Engle-Granger-Yoo Three-Steps Approach tackles the problems of biasedness and deviation from normality of the long-run model. The estimated $\beta$ in first step is written as $\beta^{1}$. The lagged residuals are added to the set of explanatory variable in the long-run model. The speed of adjustment $-(1-\alpha)$ is estimated using the residuals of the second step regression $e_{t}=\delta\left[(1-\alpha) X_{t-1}\right]+v_{t}$ to obtain an estimate $\hat{\delta}$ for $\delta$. Finally we get $\beta^{3}=\beta^{1}+\hat{\delta}$.

3.4.3 Vector Error Correction Model: VECM defines the vector $Z_{t}\left(y_{1 t}, y_{2 t}, x_{t}\right)^{\prime}$ where $z_{t}=A_{1} Z_{1}+\cdots+A_{k} Z_{k}+$ $\mu_{t} ; \mu \sim I N(0, \Sigma)$. Then Vector Error Correction is written as follows: $\Delta Z_{t}=\Gamma_{1} Z_{t-1}+\cdots+\Gamma_{k} \Delta Z_{t-k}+\Pi Z_{t-k-1}+$ $\mu_{t} ; \mu_{t} \sim I N(0, \Sigma)$

where $\Gamma_{i}=\left(\alpha-A_{1}-\cdots-A_{i}\right) ;(i=1,2, \cdots, k-1) ; \Pi=-\left(1-A_{1}-\cdots-A_{k}\right)$

3.4.4 Vector Error Correction Models: the vector autoregressive (VAR) model is a general framework used to describe the dynamic interrelationship among stationary variables. So, the first step in time-series analysis should be to determine whether the levels of the data are stationary. If not, take the first differences of the series and try again.

\subsection{Data Description and Sources}

The data used in this paper for building a macroeconometric model for Sudan were collected on a yearly basis for the period 1956-2010 Table 1 present the list of included variables.

$<$ Insert Table 1 Here>

\section{Structure of the Model}

This macroeconometric model is built around the Keynesian identity to comprise: private consumption, investment, and current account in addition to gross domestic saving, demand for money and prices.

\subsection{Private Consumption}

The classical economists derive the consumption function indirectly through the analysis of investment, employment and saving. Assuming rational behavior of consumers, any excess balances should be consumed or saved. The amount saved depends on the return i.e. the rate of interest. Keynes formulated the relationship between private consumption and income assuming real expenditure is stable function of real income; the marginal propensity to consume is positive, but less than one and less than the average propensity to consume, and declines as income rises. The lagged consumption influence is interpreted by the Keynesian psychological law. Keynes considers current income as the main determinant of consumption, and at the same time there are many secondary factors such as: sales efforts i.e. an increase or decrease in the amount of selling effort may affect the total volume of consumer expenditures, given the level of income; relative prices might influence aggregate expenditure; the volume of wealth: Its original complete formulation was by Pigou, who reasoned from an abstract model of consumer behavior. The proposed relationship follows directly from a priori formulation, which makes current utility, depend on the stock of consumer wealth; the stock of money: Naïve quantity theory of money states that any excess balances given that men are rational will spend on goods and services, (Ackley 1960)

Empirical Studies: Klein-Goldberger consumption function of USA includes liquid assets as explanatory variable of consumption. Zellener using quarterly data from postwar period used liquid asset as explanatory variable. Michigan Survey Research used cross section data give some evidence of the influence of liquid assets. Kuznet collected data covering the period 1869-1929 to set a relationship between consumption, savings, and income. The Kuznets's budget do not show any tendency nor the proportion of income saved to rise with income, but verified the statement that average propensity to consume is greater than marginal propensity to consume in the short-run.

Duesenburry developed the theory of Relative Income Hypothesis emphasizing the full recognition of the social character of consumption patterns as the real understanding of the problem of consumes behavior. Consumption is 
specified by this theory to be determined by current income, current assets, expected future (non-interest) income, and expected future interest rates, in addition the current consumption of other people. Modigliani Life Cycle Hypothesis views individuals as planning their consumption and saving behavior over long periods with the intention of allocating their consumption in the best possible way of their lifetime taking into consideration the following assumption. Expectations are formed rationally, there is no liquidity constraints, interest rates and prices are constant, real interest rate expectation are not probabilistic and consumption responds to changes in the permanent income without lag. The suggested model of consumption function includes three independent variables i.e. income from labor, expected future income, and wealth at the beginning of the period.

Hall developed rational Expectations Life Cycle Hypothesis in the late seventies and et-al to be coinciding with the failure of economic models during that time. This theory is concerned with the economic variables about which the consumer forms their expectation i.e. human wealth, and lagged consumption. The final specification of the model was that current consumption was predicted to follow a random walk with trend. This form is arrived at by differentiating the additive utility function with respect to current and previous assets.

Permanent Income Hypothesis by Freidman resembles life Cycle Hypothesis to some extent but what distinguishes it is the inclusion of factors such inflation, permanent income, current income and the ratio of human capital to total wealth.

Finally Hendry built a model explaining consumer behavior in UK, putting into consideration that the model should conform to the available data, and other factors, has arrived at the Error Correction model. Many of the above theories have passed statistical and econometric tests. Other needed to be adjusted or add many other factors to them to become a reliable-forecasting tool.

$$
\Delta \mathrm{CK}_{\mathrm{t}}=\alpha_{1}+\alpha_{2} \Delta \mathrm{DIS}_{\mathrm{t}}+\mathrm{DIS}_{\mathrm{t}-1}+\alpha_{3} \mathrm{INF}_{\mathrm{t}-1}+\alpha_{4} \Delta \mathrm{INF}_{\mathrm{t}}+\alpha_{5} \mathrm{R} 1_{\mathrm{t}-1}+\mathrm{e}_{1}
$$

\subsection{Total Investment}

Investment is an important component of the GDP. It affects the supply and demand through expanding the production capacity by adding new plants and equipment and renewing the aged equipment, and hence through the demand for other sectors' products such as construction it alters the demand for labor and the income in these sectors. For this reason it should be included in the model. The major strands of investment behavior could be classified as the simple accelerator theory, liquidity theory, expected profit theory, Topin's Q theory, and neoclassical theory.

Simple Accelerator relates a desired stock of capital to output i.e. $\mathrm{K}^{*}=\mu \mathrm{Y}$, where $\mathrm{K}^{*}$ is the desired stock of capital, $\mu$ is a factor of proportionality, and $\mathrm{Y}$ is the value added. The model assumes that the actual stock of capital $\mathrm{K}$ adjusts instantaneously to the desired stock i.e. $\mathrm{K}=\mathrm{K}^{*}$. Taking this into account the net investment which is defined to be the difference between current and lagged stock of capital i.e. $\mathrm{I}_{\mathrm{t}}=\mathrm{K}_{\mathrm{t}}-\mathrm{K}_{\mathrm{t}-1}$ which in turn equal $\lambda \mu\left(\mathrm{Y}_{\mathrm{t}}-\mathrm{Y}_{\mathrm{t}-1}\right) \lambda$ is the speed of adjustment.

Flexible Accelerator Model is an extension of the above model with the alteration of the assumption of instantaneous adjustment in the following form: $\lambda\left(\mathrm{K}_{\mathrm{t}}{ }^{*}-\mathrm{K}_{\mathrm{t}-1}\right)$. Then $\mathrm{I}_{\mathrm{t}}=\mathrm{K}_{\mathrm{t}}-\mathrm{K}_{\mathrm{t}-1}=\lambda\left(\mathrm{K}_{\mathrm{t}}{ }^{*}-\mathrm{K}_{\mathrm{t}-1}\right)=\lambda \mu \mathrm{Y}_{\mathrm{t}}-\lambda \mathrm{K}_{\mathrm{t}-1}$ and the stock of capital i.e. $\mathrm{Kt}=\lambda \mu \mathrm{Y}_{\mathrm{t}}+(1-\lambda) * \mathrm{~K}_{\mathrm{t}}-1$. By continuous substitution of $\mathrm{Kt}-1$, and the addition of depreciation $\delta \mathrm{Kt}-1$ we arrive at the flexible accelerator model: $\mathrm{I}_{\mathrm{t}}=\lambda \mu \mathrm{Y}_{\mathrm{t}}+(\delta-\lambda) * \mathrm{~K}_{\mathrm{t}-1}$

Distributed Lag Model Koyck suggests that businessmen do not adjust their capital stock simply to the current level of demand for their product, but rather to the whole past output (expected normal output). The mathematical model: $\mathrm{I}_{\mathrm{t}}$ $=\mathrm{Kt}-(1-\delta) * \mathrm{~K}_{\mathrm{t}-1}=\lambda \mu \mathrm{Y}_{\mathrm{t}}+(\delta-\lambda) * \mathrm{~K}_{\mathrm{t}-1}$

Cash Flow Model: this model assumes that the main factors affecting investment expenditure are the internal cash flow, debt, and the sale of assets. The cash flow is the principal factor since the reliance on the other source involves risks of loosing control of the firm. The model is specified as follows: $\mathrm{K}^{*}=\mathrm{a}+\beta \mathrm{V}$, where $\mathrm{V}=$ profit proxies by market value of the firm.

Tobin's Q Model: according to model investment depends on the ratio of the market value of the firm according to an investment put in place to the amount of replacement i.e. q. The mathematical model was: $\mathrm{I}=\alpha \mathrm{V}+\varepsilon$, where $\mathrm{V}$ is the profit proxies the market value of the firms.

Neoclassical (Hall-Jorgenson) Model: This model utilizes the optimization technique; it seeks maximizing profits or minimizing costs. The standard model typically is not satisfied in most developing countries. Furthermore, data on key variable such as capital stock, the labor force, wages, real financial rates for debt, and equity are readily available for most developing countries.

The majority of empirical studies show that per capita GDP growth, foreign trade, capital flows, external debt, public sector borrowing requirements, inflation and interest rate are the main determinants of investment rate. Recently, there 
is an increasing emphasis on the role of the financial sector in this process, since a financial system, in essence, mobilizes saving to investment (Ucan \&Ozturk 2011).

$$
\Delta \mathrm{INV}_{\mathrm{t}}=\alpha_{1} \Delta \mathrm{CPI}_{\mathrm{t}}+\alpha_{2} \Delta \mathrm{Y}_{\mathrm{t}}+\alpha_{3} \mathrm{CPI}_{\mathrm{t}-1}+\alpha_{4} \mathrm{R} 2_{\mathrm{t}-1}+\mathrm{e}_{2}
$$

\subsection{Gross Domestic Saving}

Domestic saving and investment are strongly correlated. In an open economy an increase in domestic savings need not be translated to increased domestic investment. With complete capital mobility, investment and saving could be independent to one another. With fully effective limitations on capital mobility, domestic savings are directly translated into investment. The impact of investment on saving could be seen through the growth of output where investment is the main factor that explains growth, since investment raises the amount of physical capital per worker and therefore increases productivity. This in turn increases the income of workers relative to that of non-workers to cater for increased consumption during retirement. On the other hand growth may also reduce liquidity and borrowing constraints inducing households to increase consumption. Therefore economic growth will increase savings if concentrated in households with high saving rate. Also, with uncertain income growth could be positively correlated with saving through a precautionary (buffer stock) motive. The relationship between the terms of trade and saving depends on the expected duration of the terms of trade shocks. Moreover it is plausible that changes in terms of trade could in fact be negatively correlated with domestic saving if their improvement reduces liquidity constraints when these are affected by the availability of foreign exchange. In the life-cycle model, the age composition of the population is postulated to have a significant influence on household saving behavior. It also predicts a negative relationship between the private saving rate and dependency ratio. The current account ratio to GDP that is jointly determined with saving in countries and/or at time periods characterized by unrestricted access to net foreign lending, and is exogenously determined otherwise. By treating current account as an endogenous variable the resulting estimates show than an increase in external saving (worsening of current account deficit) affects the saving ratio positively (Elbadawi and Mwega 1998). Inflationary expectations lead to a lower real rate of interest and adversely affect private saving. High inflation may also signal a lack of credibility in government policies as well as reduced expected return on saving.

$$
\Delta \mathrm{S}_{\mathrm{t}}=\alpha_{1} \Delta \mathrm{INF}_{\mathrm{t}}+\alpha_{2} \Delta \mathrm{CABK}_{\mathrm{t}}+\alpha_{3} \Delta \mathrm{XDOT}_{\mathrm{t}}+\alpha_{4} \mathrm{~S}_{\mathrm{t}}+\alpha_{5} \mathrm{R}_{\mathrm{t}-1}+\mathrm{e}_{3}
$$

\subsection{Demand for Money}

The classical economists laid the foundation for theoretical developments of the demand function. Their efforts were manifested mainly in the Quantity theory of money and Cambridge approach. Keynes stimulated theoretical development through working on transaction, speculative and precautionary demand for holding real balances. The classical assumption of perfect information and negligible transaction costs limits the role of money as a store of value. The quantity theory assumes a direct and proportional relationship between the quantity of money and the price level. That is $\mathrm{MV}=\mathrm{PQ}$, where $\mathrm{M}$ is the stock of money, $\mathrm{V}$ velocity of circulation, $\mathrm{P}$ the general price level and $\mathrm{Q}$ is the total transactions. The s Cambridge approach or cash balance approach is an alternative to the quantity theory of money assumes constant velocity of circulation in the short-run and changes slowly in the long run. Cambridge approach recognizes that individuals may desire to hold money because it is thought money yields satisfaction. The demand for money is proportionally related to prices and production i.e. $\mathrm{M}=\mathrm{KPY}$, where $\mathrm{M}, \mathrm{P}$, and $\mathrm{Y}$ are defined as above, while $\mathrm{k}$ is a proportionality factor assumed to vary with time, and depends on returns on alternative assets. The neoclassical economists considered the primary role of money as a medium of exchange. It was sought for the command over goods and services that it provided. Money was economical interesting as it was spent and circulated throughout the system. Its store of value function was also emphasized. Keynes specified the transaction model of the real demand for money as function of output and investment i.e. $m=\alpha_{1} Y-\beta r$, where $\mathrm{Y}$ is output, $\mathrm{r}$ is the rate of interest, and $\mathrm{I}$ is investment (Cuthberton1985). The depreciation of exchange rate plays an important role in the demand for holding real balances due to the increasing dollarization in the Sudanese economy, and the importance of foreign currency as an alternative to domestic money in the wealth portfolio, thus the model is as follows:

$$
\Delta \mathrm{MS}_{\mathrm{t}}=\alpha_{1} \Delta \mathrm{CPI}_{\mathrm{t}}+\alpha_{2} \Delta \mathrm{X}_{\mathrm{t}}+\alpha_{3} \mathrm{MS}_{\mathrm{t}-1}+\alpha_{4} \mathrm{R}_{\mathrm{t}-1}+\mathrm{e}_{4}
$$

\subsection{Consumer Price Index}

Consumer price index is a weighted average of high, medium, and low-income group's indexes. The basket of goods and service derived based on household surveys. The basket of goods and service is revised from time to time. It comprises food and beverages, residence, cloths and foot wear, household products, health services, transportation, entertainment, and miscellaneous. The index is complied for three groups of income in Sudan i.e. low income, middle income, and high-income group. Keynes assumes that at full employment the increase in investment demand increases 
the aggregate demand in excess of the available resources. Prices are bid up. Since consumer demand depends on real income, which is not reduced by rising prices because the sale of output at higher prices creates an equivalent rise in money incomes. If the $\mathrm{M}$ were constant an increase in the level of prices would raise transaction demand and thus push up interest rate to eliminate the extra investment. Since some cash was extracted from the speculation to transaction then security prices would fall. This in turn removes part of excess demand. The main Cost push factor is the increase in wage. Quantity theory postulate mechanical relationship between price, and money. The depreciation of exchange rate plays an important role in the demand for holding real balances due to the increasing dollarization in the Sudanese economy, and the importance of foreign currency as an alternative to domestic money in the wealth portfolio and

$$
\Delta \mathrm{CPI}_{\mathrm{t}}=\alpha_{1} \Delta \mathrm{X}_{\mathrm{t}}+\alpha_{2} \Delta \mathrm{MS}_{\mathrm{t}}+\alpha_{3} \mathrm{R}_{\mathrm{t}-1}+\mathrm{e}_{5}
$$

\subsection{Current Account Balance}

A key insight from the studies on oil and the macroeconomy is that the magnitude of the effect of an effect of oil price shock on gross output must be small. Assuming an aggregate production function with three inputs (labor, capital, and oil), at full employment equilibrium marginal productivity of oil equals the ratio of oil to output prices, i.e., the marginal cost of oil measured in terms of domestic product. An increase in price of oil raises its cost above marginal product leading to a cutback in amount of oil used in the production. In the process, marginal productivity of labor and capital declines and there is a fall in output. Lower the elasticity of substitution between oil and other inputs, larger will be the fall in GDP (Bhanumurthy etal 2012).

As said above the current account that is jointly determined with saving in countries and/or at time periods characterized by unrestricted access to net foreign lending, and is exogenously determined otherwise. Oil affects the current account positively and its value added is expected to enhance growth

$$
\Delta \mathrm{CABK}_{\mathrm{t}}=\alpha_{1} * \Delta \mathrm{OIL}_{\mathrm{t}}+\alpha_{2} \Delta \mathrm{INV}_{\mathrm{t}}+\alpha_{3} \mathrm{R} 6(-1)+\mathrm{e}_{6}
$$

\section{Empirical Results and Discussion}

\subsection{Empirical Results}

\section{Consumption Function:}

$$
\Delta C K_{t}=0.38 \Delta D I S_{t}+0.10 D I S_{t-1}-9.54 I N F_{t-1}-14.94 \Delta I N F_{t}-0.33 E C
$$

Disposable income and inflation rate have the expected signs and significantly different from zero at both short-run and long-run. Error correction term got the right sign, significantly different from zero, and is less than zero. This means that if consumption $1 \%$ is out of equilibrium $33 \%$ adjustment towards equilibrium will take place within the first year.

\section{Investment Function}

$$
\Delta I N V_{t}=0.10 \Delta C P I_{t}+0.48 \Delta Y_{t}+0.008 C P I_{t-1}-0.58 E C
$$

The long-run effect of consumer price index and income and the short-run effect of consumer price index are positive and significantly different from zero at $1 \%$ level. The error correction term is negative and significantly different from zero at $1 \%$ level. This means that if investment $1 \%$ is out of equilibrium $58 \%$ adjustment towards equilibrium will take place within the first year.

\section{Consumer Price Index}

$$
\Delta C P I_{t}=63 \Delta X_{t}+0.02 \Delta M S_{t}-0.53 E C
$$

Both the long-run effets of exchange rate and money supply are signifiant at $1 \%$. The error correction term is as expected negative and significant at $1 \%$. This means that if consumer price index $1 \%$ is out of equilibrium $53 \%$ adjustment towards equilibrium will take place within the first year.

\section{Demand for Money (Money Supply)}

$$
\Delta M S_{t}=33.2 \Delta C P I_{t}-1921.7 \Delta X_{t}+0.08 M S_{t-1}-0.48 E C
$$

The consumer price index and exchange rate affect money supply in the long-run with different signs, the error term is negative and as the other explanatory variables significantly different from zero at $1 \%$ level. This means that if demand for money $1 \%$ is out of equilibrium $48 \%$ adjustment towards equilibrium will take place within the first year.

\section{Saving Function}

$$
\Delta S_{t}=-16.39 \Delta I N F_{t}+1.01 \Delta C A B K_{t}+5.2 \Delta X D O T_{t}+0.259 S_{t-1}-0.93 E C
$$

It is expected that inflationary expectations lead to a lower real rate of interest and adversely affect private saving so the inflation affects saving adversely in the long-run. Current account affects saving positively in the long-run so as does 
the growth rate of exchange rate. All coefficients are different from zero at $1 \%$ level of significance. The error correction term is as expected negative and less than one. This means that if gross domestic saving $1 \%$ is out of equilibrium $93 \%$ adjustment towards equilibrium will take place within the first year.

\section{Current Account Balance}

$$
\triangle C A B K_{t}=1.1 * \Delta O I L_{t}-0.42 \Delta I N V_{t}-0.64 E C
$$

The value added of oil affects the current account positively in long-run in contrast to investment. The error term is negative and as the other variables is different form zero at $1 \%$ level of significance. This means that if current account balance $1 \%$ is out of equilibrium $33 \%$ adjustment towards equilibrium will take place within the first year.

\subsection{Discussion}

There no coherent income policy in Sudan to cope with the evolution of macroeconomic indicators in general and inflation in particular. Many committees and a council for wages were announced but the outcome has been disappointing and led to erosion of real disposable income. The effects were obvious from the empirical results whereas the short-run is more influential than the long-run. On the other hand inflation has been sowing accompanied with the possibility of simultaneous feed back with uncertainty (Arabi 2010). Despite the importance of private consumption as the major component of GDP the current and previous policies did not pay it the deserved attention. Surprisingly output affects investment only in the short-run. This can be attributed to the inconsistent macroeconomic policies that changes frequently during and within the rule of seven consecutive regimes. Capitalism was the prevailing economic system since independence in 1956 until 1970 where socialist ideology was adopted for few years witnessed the confiscation and nationalization of private companies. Capitalism was referred to again, followed by the introduction of Islamic laws. Investment acts were formulated and amended fifth times. On the contrary growing price were inductive to investment in the short-run and long-run. Empirical studies showed the dominance of saving investment gap over the foreign gap caused by excess capacity, capital productivity, and reliance on primary production as a main source of economic activity. The influence of saving - investment gap was obvious. Starting oil production in 1999 has a considerable value added to the economy and enhances growth. Another macroeconomic policy which has a profound effect is the devaluation of the exchange rate. There is negative and statistically significant leverage effect indicating the existence negative correlation between past returns and future volatility. As the past few years prove highly leveraged financial systems can have crises that increase the volatility of exchange prices (Arabi 2012). The estimated simultaneous equations model ensures the mutual effects among investment, prices, exchange rate, and monetary policy.

\section{Conclusions}

The main objective of this paper has been to develop a macroeconometric model for the Sudan to be used as an analytical tool to describe the operation of the economy. The model is built around the Keynesian identity to comprise: private consumption, investment, and current account in addition to gross domestic saving, demand for money and prices. Based on error correction model framework, Engle-Granger two steps method was followed and a system of simultaneous equations was estimated by Three Stages Least Squares. The empirical results show that the model is compatible with economic theories. The short-run effects were more influential than the long-run. The exchange rate has the greatest influence in the Sudan economy through prices and money supply. To conclude the exchange rate policy should be reversed since it has not achieved its goal; on the contrary it aggravated the economic situation.

\section{References}

Ackley Gardner. (1960). Macroeconomic. The Macmillan Company.

Alogoskoufis George. (1991). On Error Correction Models: Specification, Interpretation and Estimation. University of London.

Arabi Khalafalla Ahmed Mohamed. (2002). Macroeconometric Model of the Sudan. Unpublished PhD University of Khartoum.

Arabi Khalafalla Ahmed Mohamed. (2002, June). The Application of Two Gap Analysis to the Sudan Economy. Scientific Journal of Sudan Academy for Science.

Arabi Khalafalla Ahmed Mohamed. (2010). Association between Inflation and its Uncertainty. Journal of Business Quarterly, 2(1).

Arabi Khalafalla Ahmed Mohamed. (2012). Estimation of Exchange Rate Volatility via GARCH Model Case Study Sudan 1979-2009. International Journal of Economic and Finance, 4(11). 
Asari Fadli Fizari Abu Hassan, Nurul Syuhada Baharuddin, Nurmadihah Jusoh, \& Hadjimatheou G. (1987). Consumer Economics after Keynes. Wheatsheaf.

Banaerjee Anindya, Donaldo Juan, John W, Galbraith, \& David F Hendry. (1993). Co-integration, Error Correction, and the Econometric Analysis of Non-stationary Data. Oxford University Press.

Bhanumurthy N R, Surajit Das, \& Sukanya Bose. (2012). Oil Price Shock, Pass-through Policy and its Impact on India. Working Paper No 99-2012. National Institute of Public Finance andPolicy New Delhi.

Charemza, W.W., \& D.F.Deadman. (1992). New Directions in Econometric Practice. Edward Elgar.

Cuthberton, K.C. (1985). The Demand and Supply of Money. Blackwell

De Boef Suanna. (2000, Oct). Modeling Equilibrium Relationships: Error Correction Models with Strongly Autoregressive Data. Political Analysis, 9, 1.

Duesenberry, J., et al. (1965). The Brookings Quarterly Econometric Model of the United States. Chicago. Rand McNally.

Edison, H. J., J. R. Marquez, \& R. W. Tryon. (1987). The Structure and the Properties of the Federal Reserve Board Multicountry Model. Economic Modelling, 4, 115-315. http://dx.doi.org/10.1016/0264-9993(87)90015-0

Elbadawi Ibrahim A., \& Francis M Mwega. (1998, Sep). Can Africa's Saving Collapse be reverted. World Bank.

Gagnon, J. E. (1991). A Forward -Looking Multicountry Model for Policy Analysis: MX3. Economic and Financial Computing, 1, 311-361.

Helliwell, J. F., G. Meredith, P. Bagnoli, \& Y. Durand. (1990). INTERMOD 1.1: A G-7 Version of the IMF's Multimod. Economic Modelling 7, 3-62. http://dx.doi.org/10.1016/0264-9993(90)90007-Q

Janeš Aleksander. (2012). Error Correction Model for the Service Company. University of Primorska.

Keele Luke, \& De Boef Susanna. (2004). Not Just for Cointegration: Error Correction Models with Stationary Data. Political Analysis.

Klein, L., \& A. Goldberger. (1955). An Econometric Model of the United States, 1929-1952. Amsterdam: North-Holland.

Klein, L., R. J. Ball, A. Hazelwood, \& P. Vandome. (1961). An Econometric Model of the United Kingdom. Oxford Blackwell.

Lau Sau-Him Paul. (2004). Using an error-correction model to test whether endogenous long-run growth exists. University of Hong Kong.

McKibbin, W. J., \& J. D. Sachs. (1991). Global Linkages: Macroeconomic Interdependence and Cooperation in the World Economy. Washington, DC: Brooking Institute.

Pandit, V. (1999). Macroeconometric Modeling for India: A Review of Some Analytical Issues. Journal of Quantitative Economics, Special Issue on Policy Modeling, 15(2).

Tinbergen, J. (1939). Statistical Testing g of Business-cycle Theories. Geneva: League of Nations.

Ucan Okyay, \& Ozturk Ozlem. (2011). Financial Determinant for Turkey. Journal of Economic and Social Studies.

ZarnowitzV. (1973). Simulation and forecasting with macroeconometric models - An overview. Conference on Decision and Control - CDC , 1973, Paper No. TP4-1, pp. 463-467.

Zuraida Mohamad, Norazidah Shamsudin, \& Kamaruzaman Jusoff. (2011). A Vector Error Correction Model (VECM) Approach in Explaining the Relationship between Interest Rate and Inflation towards Exchange Rate Volatility in Malaysia. World Applied Sciences Journal, 12, (Special Issue on Bolstering Economic Sustainability), 49-56. 
Table 1. List of variables, their description and sources

\begin{tabular}{lll}
\hline Variable & Description & Source \\
\hline CK & Real Private Consumption & Central Bureau of Statistics \\
DIS & Real Disposable Income & Central Bureau of Statistics \\
INF & Inflation Rate & Central Bureau of Statistics \\
INV & Real Total Investment & Central Bureau of Statistics \\
CPI & Consumer Price Index & Central Bank of Sudan \\
Y & Real GDP & Central Bureau of Statistics \\
X & Nominal Exchange Rate & Central Bank of Sudan \\
Ms & Money Supply & Central Bank of Sudan \\
CABK & Real Current Account Balance & Central Bureau of Statistics \\
XDOT & Growth Rate of the Exchange Rate & Central Bureau of Statistics \\
S & Real Domestic Saving & Central Bureau of Statistics \\
Oil & Real Value Added of Oil & Central Bureau of Statistics \\
\hline
\end{tabular}

Annex 1

Engle-Granger First Step (Cointegration Tests)

Consumption Function

ADF Test Statistic

$$
\begin{array}{cll}
-3.80453 & 1 \% & \text { Critical Value* } \\
& 5 \% & \text { Critical Value } \\
& 10 \% \text { Critical Value }
\end{array}
$$

*MacKinnon critical values for rejection of hypothesis of a unit root.

Investment Function

ADF Test Statistic

$$
\begin{array}{clc}
-3.82749 & 1 \% & \text { Critical Value* } \\
& 5 \% & \text { Critical Value } \\
& 10 \% \text { Critical Value }
\end{array}
$$

* MacKinnon critical values for rejection of hypothesis of a unit root.

Gross Domestic Saving

ADF Test Statistic

$$
\begin{array}{clc}
-4.15083 & 1 \% & \text { Critical Value* } \\
& 5 \% & \text { Critical Value } \\
& 10 \% \text { Critical Value }
\end{array}
$$

*MacKinnon critical values for rejection of hypothesis of a unit root.

\section{Demand for Money}

ADF Test Statistic

$$
\begin{array}{clc}
-4.00738 & 1 \% & \text { Critical Value* } \\
& 5 \% & \text { Critical Value } \\
& 10 \% \text { Critical Value }
\end{array}
$$

*MacKinnon critical values for rejection of hypothesis of a unit root.

\section{Consumer Price Index}

ADF Test Statistic

$$
-4.10329 \quad 1 \% \quad \text { Critical Value* }
$$




\section{5\% Critical Value \\ $10 \%$ Critical Value}

*MacKinnon critical values for rejection of hypothesis of a unit root.

Current Account Balance

ADF Test Statistic

$$
\begin{aligned}
& -2.84868 \quad 1 \% \quad \text { Critical Value* } \\
& \text { 5\% Critical Value } \\
& 10 \% \text { Critical Value }
\end{aligned}
$$

*MacKinnon critical values for rejection of hypothesis of a unit root.

\section{Engle - Granger Second Step (Estimation of Error Correction Simultaneous Equations Model)}

System: ERRORCORRECTION

Estimation Method: Three-Stage Least Squares

Date: 11/30/12 Time: 22:42

Sample: 19572009

Included observations: 53

Total system (unbalanced) observations 303

$\mathrm{C}(1)$

$\mathrm{C}(2)$

$\mathrm{C}(3)$

$\mathrm{C}(4)$

C(5)

$\mathrm{C}(6)$

$\mathrm{C}(7)$

$\mathrm{C}(8)$

$\mathbf{C}(9)$

$\mathrm{C}(10)$

$\mathrm{C}(11)$

C(12)

$\mathrm{C}(13)$

$\mathrm{C}(14)$

$\mathrm{C}(15)$

C(16)

$\mathrm{C}(17)$

$\mathrm{C}(18)$

$\mathrm{C}(19)$

$\mathrm{C}(20)$

C(21)

$\mathrm{C}(22)$

C(23)

C(24)
Coefficient

$$
\begin{array}{r}
0.38 \\
0.10 \\
-9.54 \\
-14.94 \\
\mathbf{- 0 . 3 3} \\
0.01 \\
0.48 \\
0.008
\end{array}
$$

$\mathbf{- 0 . 5 8}$

63.00

0.02

$-0.53$

33.20

$-1921.70$

0.08

$\mathbf{- 0 . 4 8}$

$-16.39$

1.01

5.29

0.25

$-0.93$

1.10

$-0.42$

$-0.64$
Std. Error

0.10

0.02

2.70

6.28

0.10

0.00

0.09

0.00

0.10

8.35

0.00

0.11

3.43

432.66

0.01

0.08

5.48

0.31

0.76

0.09

0.14

0.32

0.07

0.13
t-Statistic

Prob.

$$
3.88
$$

4.75

$-3.54$

$-2.38$

$-3.45$

3.00

5.07

$-3.86$

$-5.65$

7.54

18.81

$-4.99$

9.69

$-4.44$

5.89

$-5.91$

$-2.99$

3.23

6.98

2.74

$-6.67$

3.47

$-6.13$

$-4.87$
0.00

0.00

0.00

0.02

0.00

0.00

0.00

0.00

0.00

0.00

0.00

0.00

0.00

0.00

0.00

0.00

0.00

0.00

0.00

0.01

0.00

0.00

0.00

0.00 
Determinant residual covariance $\quad 1.03 \mathrm{E}+39$

Equation: $\mathrm{D}(\mathrm{CK})=\mathrm{C}(1) * \mathrm{D}(\mathrm{DIS} 1)+\mathrm{C}(2) * \mathrm{DIS} 1(-1)+\mathrm{C}(3) * \mathrm{INF}(-1)+\mathrm{C}(4) * \mathrm{D}(\mathrm{INF})+\mathrm{C}(5) * \mathrm{R} 1(-1)$

Observations: 48

R-squared

$0.724215 \quad$ Mean dependent var

283.2259

Adjusted R-squared

$0.69856 \quad$ S.D. dependent var

1073.094

S.E. of regression

$589.1662 \quad$ Sum squared resid

14926023

Durbin-Watson stat

1.693503

Equation: $\mathbf{D}(\mathrm{INV})=\mathbf{C}(6) * \mathrm{D}(\mathrm{CPI})+\mathbf{C}(7) * \mathrm{D}(\mathrm{Y})+\mathbf{C}(8) * \mathbf{C P I}(-1)+\mathbf{C}(9) * \mathbf{R} 2(-1)$

Observations: 52

R-squared

$0.535152 \quad$ Mean dependent var

84.0624

Adjusted R-squared

$0.506099 \quad$ S.D. dependent var

481.0578

S.E. of regression

$338.0782 \quad$ Sum squared resid

5486249

Durbin-Watson stat

1.466494

Equation: $D(C P I)=C(10) * D(X)+C(11) * D(M S)+C(12) * R 3(-1)$

Observations: 53

R-squared

0.802474 Mean dependent var

13925.27

Adjusted R-squared

0.794573

S.D. dependent var

23877.4

S.E. of regression

10822.21

Sum squared resid

$5.86 \mathrm{E}+09$

Durbin-Watson stat

1.641051

Equation: $D(M S)=C(13) * D(C P I)+C(14) * D(X)+C(15) * M S(-1)+C(16) * R 4(-1)$

Observations: 53

R-squared

$0.855556 \quad$ Mean dependent var

534235.3

Adjusted R-squared

$0.846713 \quad$ S.D. dependent var

1211548

S.E. of regression

474344.4

Sum squared resid

$1.10 \mathrm{E}+13$

Durbin-Watson stat

1.483426

Equation: $\mathrm{D}(\mathrm{S})=\mathrm{C}(17) * \mathrm{D}(\mathrm{INF})+\mathrm{C}(\mathbf{1 8}) * \mathrm{D}(\mathrm{CABK})+\mathrm{C}(19) * \mathrm{D}(\mathrm{XDOT})+\mathrm{C}(20) * \mathrm{~S}(-1)+\mathrm{c}(21) * \mathrm{R5}(-1)$

Observations: 48

R-squared

$0.734529 \quad$ Mean dependent var

$-7.60072$

Adjusted R-squared

0.709834

S.D. dependent var

1518.712

S.E. of regression

818.0848

Sum squared resid

28778295

Durbin-Watson stat

1.906387

Equation: $\mathrm{D}(\mathrm{CABK})=\mathrm{C}(22) * \mathrm{D}(\mathrm{OIL})+\mathrm{C}(23) * \mathrm{D}(\mathrm{INV})+\mathrm{C}(24) * \mathrm{R} 6(-1)$

Observations: 49

R-squared

0.580191

Mean dependent var

$-32.0627$

Adjusted R-squared

0.561939

S.D. dependent var

341.3249

S.E. of regression

225.91

Sum squared resid

2347626

Durbin-Watson stat

1.73506

\section{Cointegration Results}

Date: 11/29/12 Time: 21:06

Sample: 19562010

Included observations: 48 
Test assumption: Linear deterministic trend in the data

Series: CK DIS1 INF

Lags interval: 1 to 1

\begin{tabular}{|c|c|c|c|c|}
\hline & Likelihood & 5 Percent & 1 Percent & Hypothesized \\
\hline Eigen value & Ratio & Critical Value & Critical Value & No. of $\mathrm{CE}(\mathrm{s})$ \\
\hline 0.432724 & 42.94861 & 29.68 & 35.65 & None $* *$ \\
\hline 0.230805 & 15.73694 & 15.41 & 20.04 & At most $1 *$ \\
\hline 0.063347 & 3.141251 & 3.76 & 6.65 & At most 2 \\
\hline
\end{tabular}

$*(* *)$ denotes rejection of the hypothesis at $5 \%(1 \%)$ significance level

L.R. test indicates 2 cointegrating equation(s) at $5 \%$ significance level

Date: 11/29/12 Time: 21:11

Sample: 19562010

Included observations: 51

Test assumption: Linear deterministic trend in the data

Series: INV CPI Y

Lags interval: 1 to 1

\begin{tabular}{|c|c|c|c|c|}
\hline & Likelihood & 5 Percent & 1 Percent & Hypothesized \\
\hline Eigen value & Ratio & Critical Value & Critical Value & No. of CE(s) \\
\hline 0.360658 & 43.27314 & 29.68 & 35.65 & None $* *$ \\
\hline 0.280466 & 20.46004 & 15.41 & 20.04 & At most $1 * *$ \\
\hline 0.069494 & 3.67334 & 3.76 & 6.65 & At most 2 \\
\hline
\end{tabular}

$*(* *)$ denotes rejection of the hypothesis at $5 \%(1 \%)$ significance level

L.R. test indicates 2 cointegrating equation(s) at $5 \%$ significance level

Date: $11 / 29 / 12$ Time: $21: 13$

Sample: 19562010

Included observations: 52

Test assumption: Linear deterministic trend in the data

Series: CPI X MS

Lags interval: 1 to 1

\begin{tabular}{|c|c|c|c|c|}
\hline & Likelihood & 5 Percent & 1 Percent & Hypothesized \\
\hline Eigen value & Ratio & Critical Value & Critical Value & No. of $\mathrm{CE}(\mathrm{s})$ \\
\hline 0.682512 & 113.998 & 29.68 & 35.65 & None $* *$ \\
\hline 0.549397 & 54.33764 & 15.41 & 20.04 & At most $1 * *$ \\
\hline 0.219474 & 12.88493 & 3.76 & 6.65 & At most $2 * *$ \\
\hline
\end{tabular}

$*(* *)$ denotes rejection of the hypothesis at $5 \%(1 \%)$ significance level

L.R. test indicates 3 cointegrating equation(s) at $5 \%$ significance level

Date: 11/29/12 Time: 21:14

Sample: 19562010

Included observations: 52 
Test assumption: Linear deterministic trend in the data

Series: MS CPI X

Lags interval: 1 to 1

\begin{tabular}{|c|c|c|c|c|}
\hline & Likelihood & 5 Percent & 1 Percent & Hypothesized \\
\hline Eigen value & Ratio & Critical Value & Critical Value & No. of $\mathrm{CE}(\mathrm{s})$ \\
\hline 0.682512 & 113.998 & 29.68 & 35.65 & None $* *$ \\
\hline 0.549397 & 54.33764 & 15.41 & 20.04 & At most $1 * *$ \\
\hline 0.219474 & 12.88493 & 3.76 & 6.65 & At most $2 * *$ \\
\hline
\end{tabular}

$*(* *)$ denotes rejection of the hypothesis at $5 \%(1 \%)$ significance level

L.R. test indicates 3 cointegrating equation(s) at $5 \%$ significance level

Date: $11 / 29 / 12$ Time: $21: 16$

Sample: 19562010

Included observations: 47

Test assumption: Linear deterministic trend in the data

Series: S2 CABK INF XDOT

Lags interval: 1 to 1

\begin{tabular}{|c|c|c|c|c|}
\hline & Likelihood & 5 Percent & 1 Percent & Hypothesized \\
\hline Eigen value & Ratio & Critical Value & Critical Value & No. of CE(s) \\
\hline 0.568035 & 86.77801 & 47.21 & 54.46 & None $* *$ \\
\hline 0.461083 & 47.32572 & 29.68 & 35.65 & At most $1 * *$ \\
\hline 0.279674 & 18.27061 & 15.41 & 20.04 & At most $2 *$ \\
\hline 0.058881 & 2.852213 & 3.76 & 6.65 & At most 3 \\
\hline
\end{tabular}

$*(* *)$ denotes rejection of the hypothesis at $5 \%(1 \%)$ significance level

L.R. test indicates 3 cointegrating equation(s) at 5\% significance level

Date: $11 / 29 / 12$ Time: $21: 18$

Sample: 19562010

Included observations: 48

Test assumption: Linear deterministic trend in the data

Series: CABK OIL INV

Lags interval: 1 to 1

\begin{tabular}{|c|c|c|c|c|}
\hline & Likelihood & 5 Percent & 1 Percent & Hypothesized \\
\hline Eigen value & Ratio & Critical Value & Critical Value & No. of CE(s) \\
\hline 0.457009 & 44.86853 & 29.68 & 35.65 & None $* *$ \\
\hline 0.227435 & 15.55673 & 15.41 & 20.04 & At most $1 *$ \\
\hline 0.063925 & 3.170872 & 3.76 & 6.65 & At most 2 \\
\hline
\end{tabular}

$*(* *)$ denotes rejection of the hypothesis at $5 \%(1 \%)$ significance level

L.R. test indicates 2 cointegrating equation(s) at $5 \%$ significance level 